\title{
Supplementation of herbals on the production performance and gastrointestinal health of layer hens
}

\author{
Novita Ardiarini ${ }^{1, *}$ and Jonathan Anugrah Lase $^{1}$ \\ ${ }^{1}$ North Maluku Assesment Institute for Agricultural Technology, Ministry of Agriculture, Indonesia
}

\begin{abstract}
This study was conducted to determine the effect of herbals on the production performance and gastrointestinal health of layer hens. There were 50 layer hens used and assigned randomly into two different types of diets namely, basal diet (T0) and basal diet $+3 \mathrm{ml}$ herbals $/ 1000 \mathrm{~g}$ ration (T1) with each treatment consisting of 25 birds. Meanwhile, the herbals supplemented into the poultry feed consisted of tumeric, sambiloto leaves, soursop leaves, ginger, and lemongrass. Consequently, the T-test results showed that supplementation of herbals on treatment 1 (T1) statistically had no significant difference with treatment control (T0). The study concluded that the herbal mix could be used as a feed supplementation in a layer basal diet. Keywords: Herbals, Gastrointestinal, Layer hens, Production performance
\end{abstract}

\section{Introduction}

The use of antibiotic growth promoters increases the antimicrobial resistance in consumers of poultry products. Therefore, the layer hen industries are looking for other additives that are safer for consumers. Herbals are medicinal plants that contain certain bioactive compounds and can be used in the livestock industry as feed additives [1]. They can be used as natural growth promoters (NGPs) developed as feed supplements to increase immunity, production performance, and gastrointestinal health [2]. Herbal mixture supplementation hopefully can improve the histomorphology and microflora of the small intestine. A previous study shows that herbals provide positive benefits in the maintenance of layer hens. Sambiloto leaf, which has a ratio of $0.4 \%$, is a type of herbal that has been reported to improve performance. Also, the herbal mix containing $2.5 \%$ of turmeric and garlic was reported to improve duodenal histomorphology and stimulate growth performance [2]. Herbals as feed additives to layer hens were expected to improve intestinal histomorphology. Based on this, an in-depth study is needed to prove its effectiveness in intestinal health. 


\section{Material and methods}

\subsection{Materials}

The mixture of herbals consisted of tumeric, sambiloto leaves, soursop leaves, ginger, and lemongrass, Layer basal diet free antibiotics, containing $2800 \mathrm{kcal} / \mathrm{kg}$ metabolism energy and $17 \%$ crude protein.

\subsection{Experiment}

A total of 50 laying hens that had been in production for 34 weeks were randomly divided into two treatment groups. A total of 25 birds for T0: basal diet with no supplementation (controls) and 25 birds for T1: basal diet supplemented with $3 \mathrm{ml}$ herbals/1000 $\mathrm{g}$ ration.

\subsection{Evaluation}

The parameters observed were production performance, which includes feed consumption. Feed consumption was calculated by weighing the remaining feed each day and comparing it to the amount of feed given. In addition, feed consumption was cumulatively calculated by summing the total weekly consumption of initial to the end of maintenance. The histomorphological parameters observed included villi height, villi width, and crypt depth. To produce the histomorphological preparate, each segment was cut $4 \mathrm{~cm}$ long and fixed with a $10 \%$ formalin solution. Then, the gastrointestinal health preparate was observed using an optical microscope. Using the Optilab viewer software, sample measurements were performed on three areas of each slide, for each parameter. Villi height was measured from the tip to the villi base and width was measured from the width of the villi base and the collected data then was analyzed by T-Test.

\section{Result and Discussion}

Table 1 shows the results of production performance and histomorphology parameters. The result showed that the poultry diets containing herbals (T1) had higher villus height, width, and crypt depth in all segments than the birds fed with the basal diet, which showed no statistical significance. Also, the herbal supplementation showed improved intestinal histology by increasing villous height and intestinal absorptive surface [3] [4]. The increase in villi height occurred because the herbals have antimicrobial properties that can inhibit the growth of pathogenic bacteria. Furthermore, medicinal plant supplementation to poultry diets can improve feed efficiency because it affects the microbial population balance [5]. Bioactive compounds contained in the herbals mix in this study were antibacterial such as alkaloids, flavonoids, and essential oils. These compounds have an antibacterial mechanism that disrupts the peptidoglycan on the bacterial cell. Herbals inhibit the production of $\beta$-lactamase from microorganisms preventing the formation of the peptidoglycan-based bacterial cell wall. They damage the cytoplasmic membrane which can inactivate the bacterial enzyme system and cause death. 
Table 1. The effect of herbals supplementation on Production performance, Villous height, width, and Crypt depth on all treatment group

\begin{tabular}{|l|c|c|}
\hline \multirow{2}{*}{\multicolumn{1}{|c|}{ Parameters }} & \multicolumn{2}{c|}{ Treatment } \\
\cline { 2 - 3 } & & T1 \\
\hline Duodenum & $1342.33 \pm 29.18^{\mathrm{ns}}$ & $1347.92 \pm 35.49^{\mathrm{ns}}$ \\
\hline Villus height $(\mu \mathrm{m})$ & $137.28 \pm 21.83^{\mathrm{ns}}$ & $139,77 \pm 26,38^{\mathrm{ns}}$ \\
\hline Villus width $(\mu \mathrm{m})$ & $180.05 \pm 0.78^{\mathrm{ns}}$ & $198.96 \pm 1.30^{\mathrm{ns}}$ \\
\hline Crypth depth $(\mu \mathrm{m})$ & & \\
\hline Jejunum & $1182.82 \pm 33.41^{\mathrm{ns}}$ & $1189.56 \pm 32.75^{\mathrm{ns}}$ \\
\hline Villus height $(\mu \mathrm{m})$ & $136.95 \pm 20.55^{\mathrm{ns}}$ & $141.05 \pm 20.05^{\mathrm{ns}}$ \\
\hline Villus width $(\mu \mathrm{m})$ & $230.74 \pm 1.50^{\mathrm{ns}}$ & $265.80 \pm 1.38^{\mathrm{ns}}$ \\
\hline Crypth depth $(\mu \mathrm{m})$ & & \\
\hline Ileum & $804.00 \pm 33.50^{\mathrm{ns}}$ & $892.22 \pm 37.73^{\mathrm{ns}}$ \\
\hline Villus height $(\mu \mathrm{m})$ & $128.80 \pm 18.87^{\mathrm{ns}}$ & $148.25 \pm 11.66^{\mathrm{ns}}$ \\
\hline Villus width $(\mu \mathrm{m})$ & $144.09 \pm 0.72^{\mathrm{ns}}$ & $164.94 \pm 0.64^{\mathrm{ns}}$ \\
\hline Crypth depth $(\mu \mathrm{m})$ & & \\
\hline Production performance & $115.76 \pm 0.50^{\mathrm{ns}}$ & $115.20 \pm 0.17^{\mathrm{ns}}$ \\
\hline Feed Intake $(\mathrm{g} / \mathrm{bird} /$ day) & $58.94 \pm 27.94^{\mathrm{ns}}$ & $59.13 \pm 21.16^{\mathrm{ns}}$ \\
\hline Egg Weight $(\mathrm{g})$ & \multicolumn{2}{|c|}{} \\
\hline
\end{tabular}

Based on Table 1, the villus height, width, and crypt depth of the ileum segment are the lowest. This is because of the pancreas activity of $\alpha$-amylase in the duodenum, which produces maltose, maltotriose, and $\alpha$-limit dextrins from the breakdown of carbohydrate complex [6]. Moreover, sucrase-isomaltase and glycosidase were widely distributed and active in the proximal jejunum. The presence of these enzymes causes the process of digestion and absorption of monosaccharides that occurs in the duodenum and jejunum segments. Herbals antioxidants could act as a defense system preventing free radicals from damaging the animal's body thereby protecting against infection and degenerative disease [7]. Additionally, the increase of villi height potentially increases the capacity of endocrine glands in producing digestive enzymes [8] and can improve digestibility and nutrient transport for the metabolic processes in the body. The absorption of nutrients in the intestine can trigger the expansion of villi resulting in optimal villi growth. Histology of duodenum, jejunum, ileum of treatment control (T0), and treatment herbal supplementation (T1) are shown in figure 1 and figure 2.

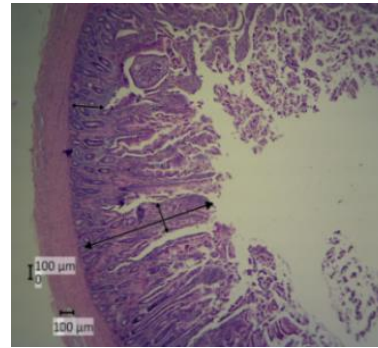

(a) Duodenum T0

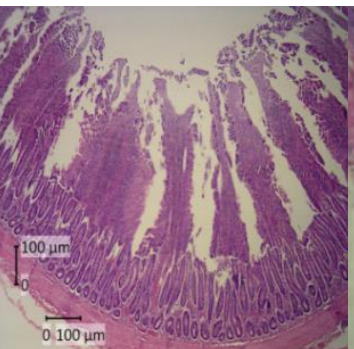

(b) Jejunum T0

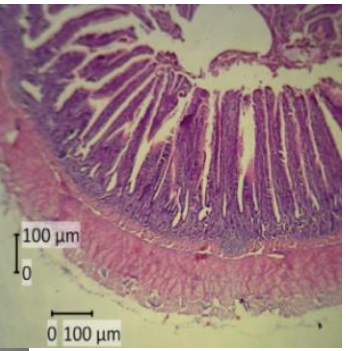

(c) Ileum T0

Figure 1. Histology of duodenum, jejunum, and Ileum of treatment control (T0) 


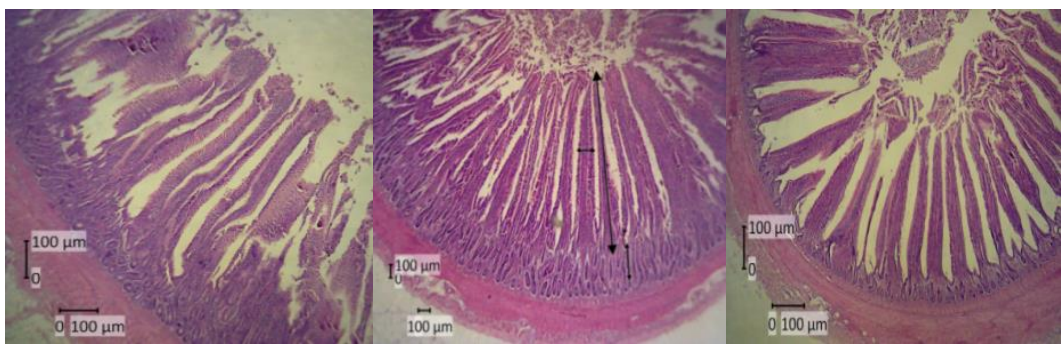

(a) Duodenum $\mathrm{T} 1$

(b) Jejunum $\mathrm{T} 1$

(c) Ileum T1

Figure 2. Histology of duodenum, jejunum, and Ileum of treatment control (T0)

The surface of the intestinal tract was coated with viscoelastic mucous gel which acts as a natural defense system and helps the absorption of nutrients [9]. Furthermore, the increase in intestinal villi height and the ratio between intestinal villi height and cryptic depth were indicative of an increase in nutrients absorption area and function [10]. Herbal mix affects the jejunum histomorphology and has a beneficial effect on the intestinal mucosa in terms of cellular infiltration, and intestinal health [11]. Histomorphology data supported the result of growth performance, indicating that the herbal supplemented treatment resulted in optimum performance than control (T0). Herbal supplementation in feed affects intestinal and pancreas enzymes activity which increased bile flow. In addition, the increase of digestive enzyme secretion could improve nutrient digestibility and production performance [12] [13]. Herbal bioactive works directly as an immune response that improves production performance [14] [15] [16].

\section{Conclusion}

Based on the result, histomorphology of villus height, width, and crypt depth in herbal supplementation treatment (T1) were not statistically different from (T0). Although in the determination, T1 was higher than T0, the herbal mix could be used as a feed additive in the layer basal diet.

\section{References}

[1] Wiedosari, E., S. Suhirman, BBR. Sembiring. Jurnal penelitian tanaman Indonesia. 20:9-16 (2014)

[2] Amad, A., AK Männer, KR Wendler, K. Neumann and J. Zentek. Poultry Science. 90: 2811-2816. (2011)

[3] Ghazanfari. S., Z. Mohammadi and AM Moradi. Brazilian J. Poultry Sci.17: 419-426. (2015)

[4] Murugesan, GR, B. Syed, S. Haldar and C. Pender. Frontiers in Vet.Sci.2: 21 (2015)

[5] Daramola, O.T., A.O. Jimoh, O.D. Oloruntola, and S.O. Ayodele. 2018. BJI. 21(3): 19 (2018)

[6] Goodman, BE. Adv. PhysiolEduc .34: 44-5 (2010)

[7] Gerzilov, V., A. Nikolov, P. Petrov, N. Nozakova, G. Penchev, and A. Bochukov. J. Central Eur Agriculture. 16:(2): 10-27. (2015)

[8] Awad, WA, K. Ghareeb, S. Abdel-Raheem and J. Böhm.PoultrySci. 88: 49-55 (2009)

[9] Arczewska, W. A., and S. Swiatkiewicz. J. Anim. Feed. Sci. 22 (3): 257-263

[10] Hong, J.C., T. Steiner, A. Aufy, T.F. Lien. Livest. Sci. 144:253-262( 2012) 
[11] Qureshi, S., M. T. Banday, I. Shakeel, S. Adil, M.S. Mir, Y.A. Beigh. and U. Amin. Veterinary world.(2016)

[12] Wang, L., XL Piao, SW Kim, XS Piao, YB Shen and HS Lee. Poultry Science 87: 12871294. (2008)

[13] Tilhonen, K., H. Kettunen, MHL Bento, M. Saarinen, S. Lahtinen, AC Ouwehand, H. Schulze and N. Rautonen. British Poultry Science. 51: 381-392. (2010)

[14] Viveros, A., S. Chamorro, M. Pizarro, I. Arija, C. Centeno and A. Brenes. Poultry Science 90: 566-578.(2011)

[15] Zhang, HY, XS Piao, Q. Zhang, P, Li, JQ Yi, JD Liu, QY Li and GQ Wang. Poultry Science. 92: 1981-1988. (2013)

[16] Zhao, XH, X. He, XF Yang and XH Zhong. Poultry Science. 92: 1343-1347. (2013) 